\title{
Beszámoló \\ a 26. Nemzetközi Evészavar Konferenciáról
}

Alpbach (Ausztria), 2018. október 18-20.

Az Alpbachi Nemzetközi Evészavar Konferencia az Innsbrucki Orvostudományi Egyetem professzora, Günther Rathner kezdeményezésére jött létre. Ez a legnagyobb német nyelvú kongresszus az evészavarok témakörében, és világviszonylatban is ez az egyik legnagyobb evészavar-kongresszus. Günther Rathner 1989-ben alapító tagja volt az Evészavarok Európa Tanácsának (European Council on Eating Disorders, ECED), a vezetésével alakult meg 1992-ben az Osztrák Evészavar-Hálózat (Netzwerk Essstörungen), és alapításától, 2000-tól az Osztrák Evészavar Társaság elnöke is volt.

A konferencia állandó helyszíne Alpbach, amit az ország legvirágosabb és Európa legszebb falujának szavaztak meg. Alpbach 1000 méterrel van a tengerszint felett, 2000-2500 méteres hegycsúcsok övezik. A falusi környezetbe belesimuló kongresszusi központ számos rendezvény helyszíne, így a "gondolkodók faluja" címet is viseli Alpbach.

Október 18-án, a kongresszus előtti továbbképző napon a plenáris előadók (Stephen Touyz, Annemarie Van Elburg és Gerard J. Butcher) tartottak - angol nyelvú - múhelyeket külön részvételi díj fejében.

A kongresszuson összesen 45 tudományos prezentációra került sor: a program 4 plenáris előadásból, 29 szekcióelőadásból és 12 múhelyból állt, 88 előadó vagy társszerző közremúködésével. A kongresszus kétnyelvú. A plenáris előadásokból 3 angolul, 1 németül hangzott el, az előadások kb. fele német, a másik fele angol nyelvú volt. A múhelyek közül 2 angol, 10 pedig német nyelven zajlott. Viszonylag sokan jöttek a szomszédos országokból: Németországból, Olaszországból és Svájcból. Létszámát tekintve a magyar csapat az 5. legnagyobb lehetett. A magyar szerzők 4 előadást tartottak. Többen jöttek a tengerentúlról, pl. Ausztráliából, Kanadából, Koreából és Kínából.

A megnyitón Karin Waldherr, az Osztrák Evészavar Társaság elnöke, Günther Rathner, az Osztrák Evészavar-Hálózat elnöke, Juliane BognerStrauss Ausztria nőkért, családokért és ifjúságért felelős minisztere és Franz Katzgraber, Tirol Tartomány egészségügyi igazgatója köszöntötte rövid beszéddel a kongresszus résztvevőit.

Mindegyik plenáris előadás az evészavarok fontos, gyakorlati jelentőségú kérdéséről szólt. Burkard Jäger a Hannoveri Orvostudományi Egyetem Pszichoszomatikus és Pszichoterápiás Klinikájáról a bulimia nervosa kezelésének 8 tézisét ismertette plenáris előadásában. A metaanalízisek eredményei szerint a kezelés után az esetek 45\%-ában érhetó el teljes remisszió, és 
gyakori a fluktuáló kórlefolyás, számos visszaeséssel. A testsúly mellett fontos figyelembe venni a beteg minimális, maximális és kívánatos testsúlyát és a "set point"-ot. A rendszeres evés a legjobb védelem a falásrohamokkal szemben. Fontos foglalkozni a törékeny önértékeléssel, a komorbid zavarok és a kórkép gyakran jelentkező szövődményei mellett.

A 2. plenáris előadást Stephen Touyz (Sydney-i Egyetem, Ausztrália) tartotta az anorexia súlyos és tartós formájáról (severe and enduring anorexia nervosa, röviden: SE-AN). Az anorexiás betegek 50\%-a reagál a családalapú terápiára vagy a kognitív viselkedésterápiára. A betegek $40 \%$-a sosem gyógyul meg, és az anorexia nervosa mortalitása a legmagasabb a pszichiátriai betegségek közül: a kezdettól számított 20 éven belül 20\%. Nem ritka, hogy a súlyhiány csökkenése mellett a betegség kialakulásában és fennmaradásában szerepet játszó pszichológiai tényezók nem változnak. Az anorexiás betegek életminősége nem jobb, mint a szkizofréniás vagy súlyos depressziós betegek életminősége, és állapotuk miatt tartósan munkaképtelenek, nagy terhet róva a családra, az őket gondozókra és az egészségügyi rendszerre. Az ellátás elsődleges célja az életminőség javítása a testsúly normalizálása mellett. Két kezelési rendszer (Cognitive Behavior Therapy [CBT-SE] és Specialist Supportive Clinical Management [SSCM-SE]) egyéves követése alapján jobb eredmény adódott a kognitív viselkedésterápia után.

A 3. plenáris előadást az evészavarosok kényszerkezelésének jogi és etikai vonatkozásairól tartotta Annemarie Van Elburg (Utrechti Egyetem).

A 4. plenáris előadást az evészavarok együttérzésen alapuló kezeléséről (Compassion-Focused Therapy, CFT) hallhattuk Gerard J. Butchertől (Trinity College, Pszichiátriai Tanszék, Dublin). Az evészavaros páciensek közül sokra jellemző a perfekcionizmus, a túlzott önkritika, a saját testtel való elégedetlenség és a szégyen. Mindezek antidótuma lehet az együttérzés, megértés. A szerző számára ez elsősorban kedvességet jelent, azt, hogy a terapeuta legyen kedves és megértő a sokat szenvedett pácienshez, akinek meg kell tanulnia, hogy maga is kedves legyen saját magához, és hogy megértse, hogyan vezethet a perfekcionizmus, önkritika, a magunkkal való elégedetlenség és szégyenérzés az evészavar tüneteihez.

A plenáris előadások után a szekcióelőadásokkal folytatódott a kongreszszus. A 7 szekció közül négyben német, háromban angol nyelven hangzott el összesen 29 előadás. A szekciók címe jelzi, hogy az érdeklődés központjában az evészavarok diagnosztikája, megelőzése és terápiája állt. Az előadások témája nagy változatosságot mutatott: szó volt az internet felhasználásáról, a MANTR-a terápiás programról, a betegek hozzátartozóit támogató online programról (SUCCEAT), a közösségi média vagy a vallás szerepéről, az orthorexia nervosáról, a férfiak evészavaráról és az orvosi szövődményekről, ígéretesnek tûnő iskolai és óvodai programokról. Az előadásokat 
több kérdés és hozzászólás követte, ezekból is sokat lehetett tanulni. A szakmai eszmecserék a szünetekben is folytatódtak, így a kongresszus együttmúködések kialakítására is alkalmat adott.

A múhelyeken a résztvevők bepillantást nyerhettek abba, hogyan valósulnak meg bizonyos terápiás módszerek a gyakorlatban, egyes elemeket, gyakorlatokat akár személyesen is kipróbálva. Mivel a 12 múhelyből párhuzamosan folyt 6-6, csak a két angol nyelvú múhelyben tudtam részt venni. Poszterszekció az idei kongresszuson sem volt.

A péntek esti fogadáson a korábbi kongresszusokhoz hasonlóan jam session volt. Új színfolt volt Lisa Mauracher énekes és billentyús kísérőjének músora, amelyhez Túry Ferenc citerájával és Bóna Enikő, a Semmelweis Egyetem doktorandusz hallgatója fuvolajátékával csatlakozott.

Összességében érdekes, hasznos és magas színvonalú volt a 26. Nemzetközi Evészavar Konferencia Alpbachban. Jövőre is itt a helyünk.

Szabó Pál

E-mail: dr.szabopal@gmail.com 